\title{
Margaret Cavendish y sus Atomic poems (1653): fusión revolucionaria de ciencia y literatura
}

MARÍA DEL MAR RIVAs CARMONA Universidad de Sevilla

Fecha de recepción: 24 febrero 2007

Fecha de aceptación: 2 junio 2007

Resumen: Margaret Cavendish, Duquesa de Newcastle, fue una personalidad descollante en el XVII no sólo como escritora, sino también como creadora de una teoría científica. Sin duda, en ambas labores fueron determinantes tanto sus experiencias vitales como el contexto histórico en que vivió (Bazeley 1990). Su obra se convierte en una respuesta a las tensiones culturales y sociales de la época y en una reivindicación de los derechos de la mujer (Charlton 2002). Es más, su teoría científica, que se aleja del mecanicismo de Hobbes y Descartes, está caracterizada por poseer una "visión femenina" de la ciencia (Rees 2003). Es la única mujer que ofreció entonces su propia visión utópica del mundo y dedicó su labor literaria a cuestiones científicas. En este marco se enmarcan sus Poemas atómicos (1653), mezcla de literatura y ciencia. El presente trabajo pretende ofrecer las claves para entender estos poemas, aparentemente confusos y absurdos, desde el contexto histórico de la Nueva Ciencia del XVII. Una lectura actual basada en los conocimientos científicos del siglo XXI, aparte de carecer de sentido, haría parecer a la autora una ilusa visionaria. En realidad, Cavendish es la fusión perfecta entre literatura, ciencia, ficción y feminismo.

Palabras clave: Margaret Cavendish. Poemas atómicos. Nueva Ciencia. Visión femenina de la ciencia. Literatura y ciencia en el XVII.

Abstract: Margaret Cavendish, Duchess of Newcastle, was a remarkable personality in both 17th c. literary and scientific fields. Undoubtedly, she must have been deeply influenced and determined by her life experience and the socio-historical context of that period (Bazeley 1990). Her work reflects the socio-cultural tensions of the time and constitutes a true vindication of women's rights (Charlton 2002). Furthermore, her scientific theory, which splits up from Hobbes and Descartes's mechanicism, is characterized by her "feminine vision" of science (Rees 2003). She was the only woman to offer then her own utopian vision of the world devoting her literary work to scientific matters. One of the examples of this blending between literature and science is her Atomic Poems (1653). The aim of this study is to offer some keys towards a relevant understanding of these apparently confusing and nonsensical poems from the historical perspective of 17th c. New Science. Today's perspective, based on 21th c. scientific knowledge, would be absurd and would make Cavendish appear as an ingenuous visionary. Far from that, Cavendish was the perfect fusion of literature, science, fiction and feminism.

Key words: Margaret Cavendish. Atomic poems. New Science. Feminine vision of science. Literature and science in the $17^{\text {th }}$ century. 


\section{LA LABOR PIONERA DE LA DUQUESA DE NEWCASTLE}

Es un hecho común el encontrar motivaciones, influencias o reflejos de sus experiencias vitales en la trayectoria literaria o en la propia obra de aquéllos que se dedican a escribir. Margaret Cavendish no es una excepción, y su labor pionera no sólo ya como escritora, sino también como creadora de una teoría científica, es fruto de su contexto histórico y vital, o, más bien, de su experiencia vital y de su lucha contra muchos rasgos del contexto histórico que le tocó vivir.

Margaret Lucas nació en 1623 y era la pequeña de los ocho hijos del matrimonio de Thomas y Elizabeth Lucas ${ }^{1}$. Los avatares de la pareja fueron determinantes en la vida de Margaret. Hubo varios hechos principales que afectaron a su familia y, por ende, marcaron su vida. En primer lugar, sus padres estaban mal considerados en su entorno tras la muerte a manos de Thomas de un aristócrata en un duelo, su posterior huida a Francia y el nacimiento fuera del matrimonio de su primer hijo. Una vez que pudieron volver a Inglaterra se casaron, pero el escándalo ya estaba servido. En segundo lugar, cuando Thomas Lucas murió en 1625, Elizabeth comenzó a dirigir el patrimonio familiar con su segundo hijo, John; sin embargo, las medidas impopulares que tomó para proteger su patrimonio la enemistaron con los campesinos y con la baja nobleza local.

El aislamiento consiguiente afectó tremendamente a la joven Margaret, puesto que se relacionó muy poco y no tuvo ocasión de conocer desde joven los intricados códigos y costumbres de las clases altas. Además, quizá por este motivo, era demasiado tímida. Tampoco veía a sus hermanos y sus familias, porque su madre había buscado sus matrimonios fuera del condado por las malas relaciones mencionadas.

Otro hecho que marcó las relaciones de Margaret con su entorno fue el modo en que su familia se vio afectada por los disturbios de 1640-1641, que darían lugar a la guerra civil. La familia, profundamente monárquica, fue acusada de apoyar con armas y caballos a Carlos II y casi fue linchada en 1642. Como señala Mendelson (1987:16), esto daría lugar a una hostilidad de por vida de Margaret hacia los habitantes de los alrededores.

También fue determinante en su vida su etapa como Dama de Honor de la reina Henrietta Maria. Su desconocimiento de las formas y las intrigas palaciegas y la insistencia de su madre en que no rompiera nunca el decoro hicieron que Margaret hablara sólo lo imprescindible, por lo empezaron a considerarla verdaderamente rara. Con la guerra civil, huyó a París con la reina y su belleza y timidez cautivaron a William Cavendish, de una de las

\footnotetext{
${ }^{1}$ Sobre su vida véanse: Sara Heller MENDELSON, The Mental World of Stuart Women: Three Studies. Amherst: University of Massachusetts Press, 1987; Douglas GRANT, Margaret the First: A Biography of Margaret Cavendish, Duchess of Newcastle 1623-1673. London: Rupert HartDavis, 1957.
} 
familias más ricas de Inglaterra, treinta años mayor que ella y muy mujeriego. Sus tímidos rechazos enamoraron al marqués y se casaron en 1645 , pese a que todos pensaban en la corte que el marqués hacía un enlace por debajo de su clase. Los primeros diecisiete años de matrimonio los pasaron en el exilio: París, Rotterdam, Amberes... Carlos II lo nombró Duque de Newcastle en 1665 por sus servicios.

Tanto Newcastle como su hermano Sir Charles Cavendish eran mecenas de las artes y ciencias. Sir Charles era aficionado a la ciencia y las matemáticas y, aunque Newcastle estaba más interesado en la cría de caballos, su hospitalidad atrajo a un grupo de intelectuales que formaron el Círculo de Newcastle en París en los años 1640. Margaret Cavendish conoció y tuvo ocasión de discutir sobre ciencia o filosofía con Thomas Hobbes, René Descartes, Marin Mersenne, Pierre Gassendi, John Pell, Sir Kenelm Digby y Sir William Petty. De aquí parte su interés por las ciencias.

En 1653 apareció su primera edición de Poems and Fancies. Entre 1653 y 1671 publicó 14 libros de temas diversos: los átomos, el movimiento y la materia, las mariposas, las pulgas, las lupas, mundos lejanos, el infinito, etc. (Merchant 1982: 270). Sintetizó sus teorías científicas en Grounds of Natural Philosophy (1668), una versión revisada de Philosophical and Physical Opinions (1655). Los géneros a los que pertenecían los escritos de Newcastle eran tan variados como su temática: poemas, obras teatrales, ensayos filosóficos, plegarias... Crawford $(1985)^{3}$ sugiere que, en parte, Cavendish se sentía animada a publicar al ver el número creciente de publicaciones femeninas de todo tipo en esa época. Sin embargo, los últimos años hasta su muerte en 1675 los dedicó a su esposo y su hacienda en lugar de a la ciencia (Mendelson 1987:59).

\section{1. ¿Pionera o transgresora?}

Durante mucho tiempo se debatió por qué Cavendish escribía piezas literarias tan raras, tan peculiares. Autoras como Rees $(2003)^{4}$ han conseguido que ahora se vea desde otra perspectiva esta singularidad de Cavendish y que lo que nos preguntemos es cómo consiguió transgredir los límites entre los géneros de la forma en que lo hizo. De hecho, se la puede considerar no sólo una exploradora, sino una verdadera transgresora de las fronteras de las formas literarias.

\footnotetext{
${ }^{2}$ Carolyn Merchant, The Death of Nature: Women, Ecology and the Scientific Revolution. London: Wildwood House, 1982.

${ }^{3}$ Patricia Crawford, "Women's Published Writings 1600-1700." Women in English Society 1500 1800. En Mary Prior (ed.), London: Methuen, 1985.

${ }^{4}$ Emma L.E. Rees, Margaret Cavendish: Gender, Genre, Exile. Manchester: Manchester University Press, 2003.
} 
Como señala Sarasohn $(1984)^{5}$, Cavendish destaca también por ser la única mujer que se atrevió a especular públicamente sobre asuntos científicos relevantes del momento. Aunque proliferaron las mujeres interesadas por la filosofía a fines del XVII, sólo se pueden destacar dos autoras que se dedicaran a la teoría científica: Cavendish y Anne Finch, Viscondesa de Conway (1631-1679).

Uno de los temas recurrentes en los escritos de Cavendish era la queja por la falta de una educación adecuada para las mujeres, semejante a la que recibían los hombres. A ellas se les enseñaba a leer, escribir, coser 0 cantar, pero no tenían acceso a las artes y las ciencia (Charlton 2002) ${ }^{6}$. La propia Cavendish señalaba: "As for tutors, although we had for all sort of Vertues, as singing, dancing, playing on Musick, reading, writing, working [i.e. needlework] and the like, yet we were not kept strictly thereto, they were rather for formalitie than benefit" (citado en Mendelson 1987:14).

Aunque algunos humanistas del Renacimiento como Sir Thomas More propugnaban una educación para las mujeres, en realidad lo que les interesaba era que pudieran enseñar a sus hijos adecuadamente. Como señala Lawrence Stone $(1979)^{7}$, gracias a la influencia de estos humanistas hubo un puñado de aristócratas que eran tan cultas como los hombres, pero pesó más la mujer inspirada en el modelo de The Courtier de Castiglione que había sido traducido al inglés en 1561, experta en música, pintura, dibujo o costura. Este ideal cortesano, protestante y puritano de la dócil ama de casa y obediente esposa llevaba a que figuras como la duquesa de Newcastle se vieran como pedantes alocadas dignas de mofa y burla; de ahí que fuera apodada "Mad Madge" ("la loca Madge"). Para intentar ganarse al público afirmaba modestamente que una mujer no puede escribir tan bien como un hombre, al igual que la hembra del mirlo no puede cantar tan bien como el macho:

It cannot be expected that I should write so wisely or wittingly as men... Men and women may be compared to the blackbirds, where the hen can never sing with so strong and loud a voice, nor so clear and perfect notes as the cock; her breast is not made with that strength to strain so high. (Citada por Gilbert y Gubar 1979:62 n.32)

La propia historia de las mujeres va de la mano del tipo de educación que recibían. Así, comenzaron escribiendo y traduciendo escritos religiosos $y$, poco a poco, hicieron sus primeros poemas religiosos, oraciones en

\footnotetext{
${ }^{5}$ Lisa T.Sarasohn, "A Science Turned Upside Down: Feminism and the Natural Philosophy of Margaret Cavendish". Huntington Library Quarterly 47, 1984, pp. 289-307.

${ }^{6}$ Kenneth Charlton, "Women and Education". En Anita Pacheco (ed.), A Companion to Early Modern Women's Writing. Oxford: Blackwell, 2002, pp. 14-18.

${ }^{7}$ Lawrence Stone, The Family, Sex and Marriage in England, 1500-1800. New York: Harper and Row, 1979.
} 
prosa, meditaciones, confesiones; de ahí pasaron a tratados sobre la maternidad, sobre los derechos de la mujer a acceder a la educación, y de ahí a la ficción en prosa o a la literatura fantástica.

Sin embargo, lo curioso era que cuando escribían tenían que disculparse en sus prólogos por tal atrevimiento. También lo hace Cavendish en el de Poems and Fancies, aunque se trata de una pura formalidad, como se puede apreciar en la dedicatoria de ese mismo volumen, "To all Noble, and Worthy Ladies":

\begin{abstract}
Condemne me not as a dishonour of your Sex, for setting forth this Work; for it is harmlesse and free from all dishonesty; I will not say from Vanity: for that is so naturall to our Sex,as it were unnaturall, not to be so. Besides, Poetry, which is built upon Fancy, Women may claim, as a worke belonging most properly to themselves: for I have observ'd, that their Braines work usually in a Fantasticall motion . . . For all I desire, is Fame, and Fame is nothing but a great noise, . . . wherefore I wish my Book may set a worke every Tongue. But I imagine I shall be censur'd by my owne Sex; and Men will cast a smile of scorne upon my Book, because they think thereby, Women incroach too much upon their Prerogatives; for they hold Books as their Crowne ... Therefore [ladies] pray strengthen my Side, in defending my Book; for I know Womens Tougns are as sharp, as two-edged Swords, and wound as much, when they are anger'd. And in this Battell may your Wit be quick, and your Speech ready, and your Arguments so strong,as to beat them out of the Feild of Dispute. So shall I get Honour..
\end{abstract}

A diferencia de la mayoría de sus contemporáneas, ella admite, claramente, que busca la fama, algo escandaloso en una mujer de su época ${ }^{8}$. Además, acusa a los hombres de sentirse amenazados por las mujeres escritoras y se excusa por hacerlo fingiendo que la poesía es un género extravagante que casa perfectamente con el estilo femenino.

\title{
2. LoS PoEMAS atómicos de MARGARET CAVENDISH
}

Para poder apreciar los Poemas Atómicos de Cavendish hace falta interpretarlos desde el punto de vista científico del siglo XVII, una lectura actual basada en los conocimientos científicos del siglo XXI carecería de sentido y haría parecer a la autora una ilusa visionaria.

Era tan profundo el interés de Cavendish por la ciencia que llegó a solicitar el permiso para acudir a una sesión de la Royal Society. La institución baconiana fundada en 1662 estaba destinada a la experimentación científica y estaba formada exclusivamente por hombres; sin embargo, debido a su posición social, no a sus méritos científicos, se admitió su presencia en

\footnotetext{
${ }^{8}$ Véase al respecto el capítulo sobre Cavendish en Mendelson (1987: 34-45).
} 
una de las reuniones. Éste se convertiría en uno de los hechos más destacados en su vida, puesto que fue la primera mujer en lograrlo. Habrían de pasar trescientos años antes de que otra mujer pisara la institución.

\subsection{Panorama científico en el XVII: la Nueva Ciencia}

El Renacimiento trajo consigo una verdadera revolución científica ${ }^{9}$ que rompía con las ideas basadas en la magia, la alquimia y la astrología medievales. De vital importancia había sido la figura de Leonardo da Vinci con su método de "ilustración científica" basado en el poder de la imaginación, la observación y la conjetura en campos tan diversos como la anatomía, la medicina, la aerodinámica, la luz, la mecánica, la arquitectura o la escultura ${ }^{10}$. Su obsesión con la idea del "movimiento" y su curiosidad intelectual, que le hizo disipar las fronteras entre distintas disciplinas ${ }^{11}$, serán de vital importancia tanto para la revolución científica del XVII como para la propia marquesa de Newcastle. Otra figura del XVI que influye por su modo de romper barreras convencionales entre disciplinas es la de Paracelso, que enlaza conocimientos de química y medicina.

Por otro lado, en el XVII se abandona la idílica visión de la madre naturaleza por una visión mecanicista y racional del mundo (Merchant 1982: $2)^{12}$. Es más, comienza a cobrar fuerza la idea del poder y dominio del hombre sobre la naturaleza ${ }^{13}$. De hecho, el capitalismo y el colonialismo junto a los avances tecnológicos hicieron que se pasara de ver la naturaleza como un objeto de adoración a un objeto de explotación. Son muy gráficas las palabras de Johannes Kepler que en 1605 comparaba el cielo no con algo divino, sino con un mecanismo de relojería: "show that the celestial machine is to be likened not to a divine organism but to a clockwork "(citado en Merchant 1982: 128).

Margaret Cavendish culpa a los hombres de este "abuso" de la naturaleza ${ }^{14}$. Como comenta Bazeley $(1990)^{15}$, los científicos del XVII querían someter a la naturaleza del mismo modo en que un hombre somete

\footnotetext{
${ }^{9}$ Véase Steven Shapin, The Scientific Revolution. Chicago: University of Chicago Press, 1996.

10 Véase la última edición del libro de Helen Gardner, Art Through the Ages, por parte de Kleiner y Mamiya; en concreto el capítulo 23 dedicado al Renacimiento. En Fred Kleiner y Christin Mamiya (eds.) Gardner's Art Through the Ages. Wadsworth, OH: Wadsworth Publishing, 2004.

${ }^{11}$ Por ejemplo, sus descubrimientos en óptica y luz los aplica a la pintura.

${ }^{12}$ Es muy curiosa la relación que Merchant (1982) señala entre estas ideas y la actual relación del hombre con el medioambiente.

${ }^{13}$ Todas estas ideas se vieron reforzadas por la visión empiricista de Francis Bacon.

${ }^{14}$ Véase Jay STEVENSON, "The Mechanist-Vitalist Soul of Margaret Cavendish." En Studies in English Literature 1500-1900. 36.3, 1996, pp. 527-43.

15 Deborah Taylor BAZELEY, "An Early English Challenge to the Precepts and Practice of Modern Science: The Fusion of Fact, Fiction, and Feminism in the Works of Margaret Cavendish, Duchess of Newcastle (1623-1673)". En DA/51, 1990, pp. 123-135.
} 
a una mujer. Por ello, la naturaleza para Cavendish es femenina y en sus versos la llama "ella": "When Nature first this World she did create" (1er verso del 1er poema de Poems and Fancies).

La Nueva Ciencia se vio, además, envuelta en un tremendo debate teológico y se llegaron a extremos como a encarcelar a Galileo hasta que se desdijo de su apoyo a la visión copernicana del universo. Cavendish, por su parte, sólo menciona una vez a Dios en su teoría científica ${ }^{16}$.

Hay críticos que opinan que Cavendish era atea y, de ahí, la ausencia de Dios en su obra. De hecho, casi se la llega a tachar de hereje y apóstata, y seguidora de los excesos de Hobbes. Así, Lisa Sarasohn (1984) encuentra ateísmo en su obra y la relaciona con Descartes, Hobbes y Gassendi: para Cavendish los átomos son "eternos e infinitos", dos atributos que sólo podrían atribuirse a Dios en la cosmología cristiana, y libres para moverse según su voluntad.

Sin embargo, para Bazeley (1990), el hecho de que deje a Dios fuera de su obra no es un signo de ateísmo, sino de distanciamiento de la polémica, que sólo servía para confundir a la gente. La creencia en Dios era simplemente algo que daba por hecho, opinaba que hay partes de la creación divina que no entendemos ni debemos intentar entender.

Ciertamente, Cavendish era contraria a las disputas entre escuelas, y entre científicos y teólogos, y pensaba que era más productivo cooperar que enfrentarse. De hecho, esta idea de "unidad" aparece reiteradamente en su obra y en su teoría atómica.

\subsection{Las teorías atómicas de la época}

Para los científicos del XVII el átomo era un tema de relevancia (Shapin 1996). La Physica Peripatetica de Johannes Magirus, que Newton estudió en Cambridge, era uno de los pilares en que se basaban. Para Magirus la materia estaba formada por cuatro elementos (aire, tierra, fuego y agua), cada uno con unas cualidades asociadas, bien "manifiestas" (como calor, humedad, frío y sequedad (1rias); color, olor, sabor, densidad, gravedad, dureza, suavidad (2rias)) o bien "ocultas", como el magnetismo o la atracción eléctrica.

También el conocido Corps de philosophie de Scipion du Pleix seguía la división de Aristóteles entre materia primaria y secundaria. La primaria sólo se encuentra en la razón, la secundaria en la naturaleza y estaba constituida por cuatro elementos formados por distintas combinaciones de

${ }^{16}$ En el poema "Of the Subtlety of Motion:"

Could we the severall Motions of Life know,

The Subtle windings, and the waies they go:

We should adore God more, and not dispute,

How they are done, but that great God can doe't. 
las cualidades primarias (calor, frío, humedad y sequedad). De este modo el fuego sería caliente y seco; el aire, caliente y húmedo; el agua, fría y húmeda; y la tierra, fría y seca.

En la década de 1620 hubo tres filósofos naturales franceses que comenzaron a estudiar la teoría atómica y la extendieron a Inglaterra por su relación con el Círculo Newcastle de París: Marin Mersenne (1588-1648), Pierre Gassendi (1592-1655), y René Descartes (1596-1650). Los tres construyeron una filosofía mecánica que resolvía problemas de certeza y estabilidad, basada en antiguos teorías pero dentro de un contexto cristiano (Merchant 1982: 194). Además, estos pilares de la filosofía mecánica, Decartes y Gassendi, junto a monárquicos como Hobbes, Newcastle, Sir Charles Cavendish y John Pell hicieron que el "atomismo" se convirtiera en un asunto de primera magnitud en la filosofía natural inglesa. La teoría de la materia de Descartes se basa en los cuerpos y sus movimientos. La de Gassendi en los átomos y el vacío. Tanto las partículas de Descartes como los átomos de Gassendi tenían distintas formas, pesos y cualidades.

\subsection{La teoría atómica de Cavendish}

La teoría atómica de Cavendish se basa en el movimiento; para la autora, tanto los fenómenos físicos como psicológicos tendrían su origen en el movimiento de los átomos ("psychological as well as physical phenomena have their origin in atomic motion.". Douglas Grant (1957:192) critica la falta de empirismo en Cavendish, pues se basaba más en conjeturas que en experimentos, un hábito por otro lado frecuente entonces, pese a que se reconocía la importancia de la experimentación.

En su teoría toda la materia está compuesta por cuatro elementos, bien en su forma pura o combinados. Son fuego, tierra, aire y agua, y están compuestos de átomos de diversas formas; los de fuego son puntiagudos, los de la tierra, cuadrados y planos; los del aire, alargados, rectos y vacíos; los del agua, redondos y vacíos. Los del fuego serían los más activos y los de la tierra, los menos activos. Para ella, todos tienen el mismo peso y la misma cantidad de material, pero varían en tamaño y forma. Cuando se unen en armonía forma las distintas partes del mundo, si no encajan surge la lucha, el cambio o la enfermedad... Para Cavendish, curiosamente, la salud está relacionada con los átomos; de ellos dependen no sólo las enfermedades o las emociones y sentimientos, sino también la duración de la vida, según el grado de unidad que tengan. Los átomos vegetales están poco unidos, los humanos mucho. Aunque si los átomos del cerebro son ligeros y fluidos dan lugar a una mente creativa, por ejemplo.

El movimiento de los átomos es fundamental, pues no sólo indica dónde están, sino que proporcionan unidad o armonía. Ambas, unidad y armonía, son la clave para la felicidad. Un átomo feliz baila al compás del 
movimiento, que, a su vez, es el que da vida a las cosas. El movimiento también explica fenómenos como la gravedad de la tierra, pues, según su teoría, los átomos puntiagudos de la tierra salían y atravesaban a otros más huecos que agarraban al volver al centro de la tierra.

La unidad es vital en su visión de los átomos, pero también de todas las cuestiones de la vida, ya sean políticas, religiosas, etc.

Aunque ahora puedan parecerlo, en el contexto de su época no son ideas absurdas. En su segundo libro, Philosophicall Fancies, de 1653, se retractó de esta teoría de los átomos, bien por las acusaciones de ateísmo que recibió o bien porque la reconsiderara, y se centró en el movimiento como base de su filosofía sobre la naturaleza. Sarasohn (1984: 294) comenta que abandonó Cavendish el atomismo en 1661 en favor de un todo órganico que componía todo el mundo. El universo estaría compuesto de material (racional, sensible e inanimado) y movimiento, inseparables los dos.

\subsection{El 'discurso' de la Nueva Ciencia}

Pese a que existían claras discrepancias mutuas entre Cavendish y los científicos de la Royal Society, que se reflejaban en el retrato satírico que de ellos hace la autora en The Blazing World o en la crítica hacia la actitud anti-femenina de éstos que hace en Philosophical and Physical Opinions, sin embargo, sí que parece existir en Cavendish cierta afinidad por el estilo retórico que propugnan desde la Sociedad. Como señala Nate $(2001)^{17}$, ella también se adhiere a la forma "plain and vulgar" que formulaban Thomas Sprat y Joseph Glanvill.

Estos principios retóricos se encuentran en el capítulo "Manner of Discourse" de la History of the Royal Society (1667) de Thomas Sprat. Como Joseph Glanvill y Samuel Parker, Sprat estimaba que el estilo en que se debía expresar la teoría científica debía huir de cualquier tipo de digresión, amplificación o cualquier exceso retórico. En concreto, el estilo simple (plain) que propugnaban se caracterizaba por la ausencia de figuras retóricas; en otras palabras, era la "retórica de lo anti-retórico", perspicuitas frente a obscuritas, genus humile frente a genus grande (Nate 2001: 409).

Esta deliberada ausencia de figuras retóricas no evitaba, sin embargo, el empleo de un lenguaje figurativo. Así, Sprat definía el estilo científico con una serie de adjetivos metafóricos (un estilo cerrado, natural, desnudo, positivo, claro y, curiosamente, "masculino") ${ }^{18}$. Sprat contrastaba

${ }^{17}$ Richard Nate, "Plain arid Vulgarly Express'd": Margaret Cavendish and the Discourse of the New Science". En Rhetorica, v. 19, otoño 2001, pp. 403-415.

${ }^{18}$ Véase B. VICKERS, "The Royal Society and English Prose Style: A Reassessment". En B. Vickers, N. S. Struever, Rhetoric and the Pursuit of Truth: Language Change in the Seventeenth and Eighteenth Centuries. Los Angeles: Berkeley University Press, 1985, pp. 3-76. 
el papel activo del científico con el papel pasivo de la naturaleza femenina, siempre situando como positivos los extremos de la dicotomía relacionados con los hombres y como negativos los relacionados con las mujeres (Lloyd 1996). Como señala Walters $(2004)^{19}$, no es de extrañar, por tanto, el rechazo mutuo que sintieron los científicos de la Royal Society y la duquesa de Newcastle.

\section{CONCLUSIÓN}

La teoría de Cavendish es una parte pequeña pero importante de la historia científica. Sus libros se encontraban ya en la biblioteca de Cambridge cuando Newton estudiaba allí. Además, su obra era una respuesta a las presiones culturales y políticas de la época y es vital para entender el papel de la mujer en la historia de la ciencia.

Su visión científica, una visión que se ha tildado de 'visión femenina' de la ciencia, aporta una teoría que es sumamente vitalista frente al mecanicismo de Hobbes y Descartes.

Se trata, además, de la única mujer que dedicó poemas a la teoría atómica en el XVII y que creó sus propias visiones utópicas del mundo.

\footnotetext{
${ }^{19}$ Lisa WALTERS, "Gender Subversion in the Science of Margaret Cavendish." En Early Modern Literary Studies 14, 2004, pp. 1-34.
} 
Atomic Poems of Margaret (lucas) Cavendish, Duchess of Newcastle, FROM HER POEMS AND FANCIES, 1653

To NAtural PHILOSOPHeRs

1653

IF any Philosophers have written of these Subjects, as I make no question, or doubt, but they have, of all that Nature hath discover'd, either in meere Thought, and Speculation, or other waies in Observation; yet it is more then I know of: for I never read, nor heard of any English Booke to Instruct me: and truly I understand no other Language; not French, although I was in France five years. Neither do I understand my owne Native Language very well; for thereare many words, I know not what they signifie; so as I have onely the Vulgar part, I meane, that which is most usually spoke. I do not mean that which is us'd to be spoke by Clownes in every Shire, where in some Parts their Language is knowne to none, but those that are bred there. And not onely every Shire hath a severall Language, but every Family, giving Marks for things according to their Fancy. But my Ignorance of the Mother Tongues makes me ignorant of the Opinions, and Discourses in former times; wherefore I may be absurd, and erre grossely. I cannot say, I have not heard of Atomes, and Figures, and Motions and Matter; but not throughly reason'd on: but if I do erre, it is no great matter; for my Discourse of them is not to be accounted Authentick: so if there be any thing worthy of noting, it is a good Chance; if not, there is no harm done, nor time lost. For I had nothing to do when I wrot it, and I suppose those have nothing, or little e'se to do, that read it. And the Reason why I write it in Verse, is, because I thought Errours might better passe there, then in Prose; since Poets write most Fiction, and Fiction is not given for Truth, but Pastime; and I feare my Atomes will be as small Pastime, as themselves: for nothing can be lesse then an Atome. But my desire that they should please the Readers, is as big as the World they make; and my Feares are of the same bulk; yet my Hopes fall to a single Atome agen: and so shall I remaine an unsettled Atome, or a confus'd heape, till I heare my Censure. If I be prais'd, it fixes them; but if I am condemn'd, I shall be Annihilated to 
nothing: but my Ambition is such, as I would either be a

World, or nothing.

I desire all that are not quick in apprehending, or will not

trouble themselves with such small things as Atomes, to skip

this part of my Book, and view the other, for feare these

may seem tedious: yet the Subject is light, and the Chapters

short. Perchance the other may please better; if not the second,

the third, if not the third, the fourth; if not the fourth, the

fifth: and if they cannot please, for lack of Wit, they may please

in Variety, for most Palates are greedy after Change. And though

they are not of the choicest Meates, yet there is none dangerous;

neither is there so much of particular Meat, as any can feare a

Surfet; but the better pleas'd you are, the better Welcome. I

wish heartily my Braine had been Richer, to make you a fine

Entertainment: truly I should have spar'd no Cost, neither have

I spar'd any Paines: for my Thoughts have been very busily im-

ployed, these eight, or nine Months, when they have not been

taken away by Worldly Cares, and Trouble, which I confesse hath

been a great hinderance to this Work. Yet have they sat up late,

and risen earely, running about untill they have been in a fiery

heat, so as their Service hath not been wanton, nor their In-

dustry slack. What is amisse, excuse it as a Fault of too much

Care; for there may be Faults committed withbeing over-bu-

sie, as soon as for want of Diligence. But those that are poore,

have nothing but their labour to bestow; and though I cannot

serve you on Agget Tables, and Persian Carpets, with Golden Di-

shes, and Chrystall Glasses, nor feast you with Ambrosia, and Nectar, yet perchance my Rye Loafe, and new Butter may tast more sa-

voury, then those that are sweet, and delicious.

If you dislike, and rise to go away,

Pray do not Scoff, and tell what I did say.

But if you do, the matter is not great,

For tis but foolish words you can repeat.

Pray do not censure all you do not know,

But let my Atomes to the Learned go.

If you judge, and understand not, you may take

For Non-sense that which learning Sense will make.

But I may say, as Some have said before,

I'm not bound to fetch you Wit from Natures Store. 
PARA LOS FILÓSOFOS NATURALES

1653

Si algún filósofo ha escrito acerca de estas materias, cosa que no cuestiono, ni me atrevo a dudar, si lo han hecho, de todos los que han descubierto la Naturaleza, bien como mero pensamiento, como especulación, o como cualquier otro tipo de observación, sería más de lo que yo alcanzo a conocer, porque nunca he leído ni he oído jamás hablar acerca de un libro en inglés [5] que me instruya al respecto. $Y$ es cierto que no hablo otras lenguas; ni siquiera francés, pese a que he vivido en Francia durante cinco años. Tampoco hablo mi propia lengua nativa demasiado bien; porque existen muchas palabras de las que desconozco el significado, por lo que sólo poseo la parte vulgar, es decir, lo que se habla más frecuentemente. Con esto no quiero decir que es la que emplean los [10] payasos en todos los distritos, en los que en algunas partes su forma de hablar no la entiende nadie, más que los que se han criado allí. Además no sólo todos los distritos tienen su propia habla, sino todas las familias, dando su propia seña a las cosas según su capricho. Mas mi ignorancia de mis lenguas madre [15] me hace desconocedora de las opiniones y discursos de otras épocas; por lo que puedo resultar absurda y errar flagrantemente. No puedo decir que no he oído hablar de átomos, de figuras, de movimientos y de material, pero no de forma totalmente razonada: si me equivoco, pues, no será un gran problema; puesto que mi discurso al respecto no se debe considerar [20] auténtico: así pues, si existe algo que merezca la pena tener en consideración, aprovechad la ocasión; si no, no habremos hecho daño alguno ni perdido el tiempo. Porque yo no tenía nada que hacer cuando lo escribí, y supongo que los demás no tienen nada o tienen poco más que hacer que leerlo. $\mathrm{Y}$ el motivo por el que lo he escrito en verso es porque pensé que los [25] errores podrían pasar mejor así que en prosa; ya que los poetas suelen escribir ficción, y la ficción no busca la verdad, sino el pasatiempo; y me temo que mis átomos serán un pequeño pasatiempo, tan pequeño como ellos mismos: ya que no hay nada menor que un átomo. Sin embargo, mi deseo de que agraden a los lectores es tan grande como el mundo que ellos [30] constituyen; y mis miedos son del mismo volumen; mas, de nuevo, mis esperanzas se convierten en un simple átomo: y, por todo esto, permaneceré como un átomo inestable, o como una masa confusa, hasta que oiga mi crítica. Si me alaban, los estabilizará; pero si me censuran, me desintegraré en la nada: pero es tal mi ambición que prefiero ser o un [35] mundo o nada. Prefiero que los que no son rápidos de percepción o los que no se molestarán en cosas tan pequeñas como los 
átomos, se salten esta parte de mi libro, y vean la otra, por temor a que ésta les parezca tediosa: aunque el tema es ligero, y los capítulos [40] son cortos. Quizá la otra les agrade más; si no el capítulo segundo, el tercero, si no el tercero, el cuarto, si no el cuarto, el quinto: y si por falta de inteligencia no les agrada ninguno, quizá les guste la variedad, porque muchos paladares se vuelven ávidos con el cambio. $Y$, aunque no se trate de las viandas más selectas, ninguno de ellos es peligroso; [45] tampoco hay tanta carne en concreto como para temer un exceso; cuanto más satisfechos estéis, mejor recibidos serán. Habría deseado de corazón que mi cerebro hubiera sido más inteligente para proporcionaros un buen entretenimiento: de veras que no habría reparado en gastos, ni habría reparado en esfuerzos: pues mis pensamientos se han empleado muy afanosamente [50] durante estos ocho o nueve meses, cuando no han sido requeridos por otros menesteres y preocupaciones mundanas, que he de confesar que han sido una gran traba para esta obra. No obstante, se han quedado hasta tarde y se han levantado temprano, deambulando hasta estar en un calor abrasador, de modo que su servicio no fuera sin sentido, ni su labor inútil [55]. Lo que no esté bien, disculpadlo como un defecto por exceso de cuidado; ya que existen tanto defectos cometidos por tener demasiado afán como defectos por falta de diligencia. Pero los que son pobres no tienen más que su trabajo para ofrecer; $y$, aunque yo no puedo serviros en mesas Agget y alfombras persas, con vajilla de oro [60] y cristalería fina, ni agasajaros con ambrosía y néctar, quizá, sin embargo, mi pan de centeno y mi manteca puedan resultar más sabrosos que esos manjares dulces y deliciosos.

Si no os gusta y os levantáis para iros, por favor no os burléis y contéis lo que he dicho.[65] Mas, si acaso lo hacéis, tampoco pasa nada, porque sólo podréis repetir necedades. Ruego no censuréis lo que no conocéis, y dejad que mis átomos vayan a los que entienden. Si juzgáis sin saber, tomaréis por absurdo aquello que sí crea el sentido educado. [70] Pero puedo deciros, como otros ya dijeron, que ingenio no he de daros surgido de Natura. 
WORLD MADE BY ATOMES

1653

Small Atomes of themselves a World may make, As being subtle, and of every shape:

And as they dance about, fit places finde,

Such Formes as best agree, make every kinde.

For when we build a house of Bricke, and Stone,

We lay them even, every one by one:

And when we finde a gap that's big, or small,

We seeke out Stones, to fit that place withall.

For when not fit, too big, or little be,

They fall away, and cannot stay we see.

So Atomes, as they dance, finde places fit,

They there remaine, lye close, and fast will sticke.

Those that unfit, the rest that rove about,

Do never leave, untill they thrust them out.

Thus by their severall Motions, and their Formes,

As severall work-men serve each others turnes.

And thus, by chance, may a New World create:

Or else predestined to worke my Fate.

UN MUNDO HECHO DE ÁTOMOS

1653

Los átomos pequeños pueden hacer un mundo, pues son imperceptibles y adoptan cualquier forma; y mientras que pululan hallan sitio adecuado, bien puestas tales formas se convierten en todo. Pues, si se hace una casa de ladrillo y de piedra, los ponemos parejos, igual de cada uno:

mas si hallamos un hueco, ya sea grande o pequeño, buscamos unas piedras con las que rellenarlo. Si no son adecuadas, son grandes o pequeñas, veremos que se caen, que allí no se mantienen. 
Al pulular, los átomos hallan un sitio justo, permanecen allí, se aprietan y se pegan.

Aquéllos que no caben, los que vagan errantes, no quieren alejarse, hasta que los empujan. Así pues, por sus formas y por sus movimientos, cual si fueran obreros cumplen con su función. $Y$ pueden por azar crear un Mundo Nuevo, o estar predestinados a trazar mi destino.

THE FOURE PRINCIPALL FIGUR'D ATOMES MAKE THE FOURE ELEMENTS, AS SQUARE, ROUND, LONG, AND SHARPE

1653

THE Square flat Atomes, as dull Earth appeare, The Atomes Round do make the Water cleere.

The Long streight Atomes like to Arrowes fly, Mount next the points, and make the Aiery Skie; The Sharpest Atomes do into Fire turne, Which by their peircing quality they burne:

That Figure makes them active, active, Light; Which makes them get aboue the rest in flight; And by this Figure they stick fast, and draw Up other Atomes which are Round and Raw: As Waters are round drops, though nere so small, Which shew that water is all sphæricall,

That Figure makes it spungy, spungy, wet, For being hollow, softnesse doth beget.

And being soft, that makes it run about; More solid Atomes thrust it in, or out;

But sharpest Atomes have most power thereon, To nip it up with Cold, or Heate to run.

But Atomes Flat, are heavy, dull, and slow,

And sinking downward to the bottome go:

Those Figur'd Atomes are not active, Light, Whereas the Longe are like the Sharp in flight.

For as the Sharpe do pierce, and get on high,

So do the long shoot streight, and evenly.

The Round are next the Flat, the Long next Round, Those which are sharp, are still the highest found: 
The Flat turne all to Earth, which lye most low,

The Round, to Water cleer, which liquid flow.

The Long to Aire turne, from whence Clouds grow,

The Sharp to Fire turne, which hot doth glow,

These Foure Figures foure Elements do make,

And as their Figures do incline, they take.

For those are perfect in themselves alone,

Not taking any shape, but what's their owne.

What Forme is else. must still take from each part,

Either from Round, or Long, or Square, or Sharp;

As those that are like to Triangulars cut,

Part of three Figures in one Forme is put.

And those that bow and bend like to a Bow;

Like to the Round, and joynted Atomes shew.

Those that are Branch'd, or those which crooked be,

You may both the Long, and sharp Figures see.

Thus severall Figures, severall tempers make,

But what is mixt, doth of the Four partake.

LOS CUATRO TIPOS PRINCIPALES DE ÁTOMOS, CUADRADOS, REDONDOS, LARGOS Y PUNTIAGUDOS, FORMAN LOS CUATRO ELEMENTOS

1653

Son planos y cuadrados los átomos de tierra, son átomos redondos los que hacen el agua, y los largos y rectos, que vuelan como flechas, se unen por las puntas, haciendo el cielo de aire; los átomos agudos se convierten en fuego, pues al ser penetrantes bien logran encenderlo: esa forma los hace activos, activos y ligeros; $y$ hace que superen a los otros en vuelo; y por esta figura muy rápido se adhieren $y$ atraen otros átomos redondos $y$ cortantes: $y$ las aguas son gotas redondas y pequeñas, que demuestran que el agua es esférica toda, esa forma la hace húmeda y esponjosa, pues, al estar vacías, adquieren suavidad. 
$Y$ puesto que son suaves discurren fácilmente; los átomos más sólidos atraen o rechazan; los átomos agudos tienen mayor poder de adherirse a lo frío, o bien a lo caliente. Mas los átomos planos son pesados y lentos, se hunden hacia abajo y llegan hasta el fondo: no es un tipo de átomo ni activo ni ligero, mientras los largos vuelan igual que los agudos. Los agudos penetran y ascienden hacia arriba, los largos vuelan rectos y de modo constante. Redondos junto a planos, largos junto a redondos, y los que son agudos se encuentran lo más alto: Los planos a la tierra, que se halla más abajo, los redondos al agua, que fluye clara y líquida. Los largos van al aire, donde surgen las nubes, los agudos al fuego, que resplandece cálido, De estas cuatro figuras surgen cuatro elementos, $y$, al inclinarse éstas, ellos mismos las toman. Porque éstos son perfectos solamente en sí mismos, no al tomar una forma, mas por la suya propia. $Y$ cualquier otra forma tomará de una parte, bien sea larga o redonda, cuadrada o angulosa; como aquéllas que tienen la forma triangular, que para una forma toman de tres figuras. $Y$ aquéllas que se doblan y curvan como un arco; aparecen unidas, como están las redondas. Y las que son sinuosas, o están ramificadas, contienen dos figuras, las largas y agudas. Las diversas figuras distinto humor provocan, lo mixto participa, sin duda, de las cuatro. 
OF AIERY ATOMES

1653

THE Atomes long, which streaming Aire makes,

Are hollow, from which Forme Aire softnesse takes.

This makes that Aire, and water neer agree,

Because in hollownesse alike they be.

For Aiery Atomes made are like a Pipe,

And watry Atomes, Round, and Cimball like.

Although the one is Long, the other Round;

Yet in the midst, a hollownesse is found.

This makes us thinke, water turnes into Aire,

And Aire often runs into water faire.

And like two Twins, mistaken they are oft;

Because their hollownesse makes them both soft.

\section{DE LOS ÁTOMOS DE AIRE}

1653

Esos átomos largos, que al fluir forma el aire, están huecos, de ahí que el aire sea suave.

Y, por esta razón, aire y agua concuerdan, porque ambos se asemejan en su condición hueca. Los átomos de aire parecen una gaita,

los átomos de agua, redondos cual platillos.

Aunque el uno es redondo y el otro es alargado; mas, en el interior, los dos están vacíos.

Esto a pensar nos lleva que el agua se hace aire y otras veces el aire en agua se convierte.

Y, como dos gemelos, a veces se confunden;

al ser ambos vacíos, los dos son muy suaves. 


\section{OFEARTH}

1653

WHY Earth's not apt to move, but slow and dull, Is, Atomes flat no Vacuum hath but full.

That Forme admits no empty place to bide

All parts are fil'd, having no hollow side.

And where no Vacuum is, Motion is slow,

Having no empty places for to go.

Though Atomes all are small, as small may bee,

Yet by their Formes, Motion doth disagree.

For Atomes sharp do make themselves a Way,

Cutting through other Atomes as they stray.

But Atomes flat will dull, and lazy lay,

Having no Edge, or point to make a Way.

DE LA TIERRA

1653

El porqué se desplaza lenta y torpe la Tierra

es por átomos planos, no vacíos, mas llenos.

Esta forma no admite lugar hueco de espera.

Sus partes están llenas, no hay hueco en su interior.

$Y$ donde no hay vacío es lento el movimiento,

porque no hay ningún sitio a donde desplazarse.

Pese a que esos átomos son realmente pequeños,

no concuerda su forma con la movilidad.

Los átomos agudos se hacen un camino,

atravesando a otros que encuentran al pasar.

Mas los átomos planos quedarán perezosos,

pues ni filo ni punta tienen para avanzar. 


\section{REFERENCIAS BIBLIOGRÁFICAS}

BAZELEY, Deborah Taylor, "An Early English Challenge to the Precepts and Practice of Modern Science: The Fusion of Fact, Fiction, and Feminism in the Works of Margaret Cavendish, Duchess of Newcastle (1623-1673)". En DA/51, 1990, pp. 123-135.

CAVEnDISH, Margaret, Philosophical Letters: or, Modest Reflections Upon Some Opinions in Natural Philosophy, Maintained by Several Famous and Learned Authors of This Age, Expressed by Way of Letters. London, 1664.

, The Philosophical and Physical Opinions. London: J. Martin and J. Allestrye, 1663. , Poems, and Fancies. London: T.R. for J. Martin and J. Allestryre, 1653.

The Blazing World and Other Writings. Ed. Kate Lilley. London: Penguin Classics, 1992.

Charlton, Kenneth, "Women and Education". En Anita PACHECo (ed.) A Companion to Early Modern Women's Writing. Oxford: Blackwell, 2002, pp. 14-18.

CRAWFORD, Patricia, "Women's Published Writings 1600-1700." Women in English Society 1500-1800. Ed. Mary Prior. London: Methuen,1985.

GRANT, Douglas. Margaret the First: A Biography of Margaret Cavendish, Duchess of Newcastle 1623-1673. London: Rupert Hart-Davis, 1957.

KLEINER, Fred y Christin MAmiYA (eds.), Gardner's Art Through the Ages. Wadsworth, OH: Wadsworth Publishing, 2004.

LLOYD, Genevieve, "Reason, Science and the Domination of Matter." En Evelyn Fox Keller y Helen E. Longino (eds.) Feminism and Science. Oxford: Oxford University Press, 1996, pp. 41-53.

Mendelson, Sara Heller, The Mental World of Stuart Women: Three Studies. Amherst: U Massachusetts P, 1987.

Merchant, Carolyn, The Death of Nature: Women, Ecology and the Scientific Revolution. London: Wildwood House, 1982.

REES, Emma L.E., Margaret Cavendish: Gender, Genre, Exile. Manchester: Manchester UP, 2003.

SARASOHN, Lisa T., "A Science Turned Upside Down: Feminism and the Natural Philosophy of Margaret Cavendish". En Huntington Library Quarterly 47, 1984, pp. 289-307.

SHAPIN, Steven, The Scientific Revolution. Chicago: University of Chicago Press, 1996.

SteVenson, Jay, "The Mechanist-Vitalist Soul of Margaret Cavendish." En Studies in English Literature 1500-1900, 36.3, 1996, pp. 527-543. 
StONE, Lawrence, The Family, Sex and Marriage in England, 1500-1800. New York: Harper and Row, 1979.

VICKERS, B., "The Royal Society and English Prose Style: A Reassessment".

En B. Vickers, N. S. Struever, Rhetoric and the Pursuit of Truth: Language Change in the Seventeenth and Eighteenth Centuries. Los Angeles: Berkeley University Press, 1985, pp. 3-76. 